UDC 616.089.843:591.81:591.3:591.88:611-018.4: 591.481.1:616-005.4-092.9:617.57/58:612.015.36

Iarmoliuk Ie. S. ${ }^{1,2}$, Tsymbaliuk V. I., ${ }^{1,2}$, Staino L. P. ${ }^{2}$, Savchuk O. V. ${ }^{3}$, Diatel M. V. ${ }^{4}$

${ }^{1}$ Bogomolets National Medical University, Kyiv, Ukraine

${ }^{2}$ A. P. Romodanov State Institute of Neurosurgery NAMS of Ukraine, Kyiv, Ukraine

${ }^{3}$ Bogomoletz Institute of Physiology NAS of Ukraine, Kyiv, Ukraine

${ }^{4}$ Kyiv City Oncology Center, Kyiv, Ukraine

e-mail: i.iarmoliuk@ukr.net

\title{
EFFECT OF TRANSPLANTATION OF CELL SUSPENSION FROM EMBRYONIC NERVOUS TISSUE AND BONE MARROW ON POSTISCHEMIC CEREBRAL ANGIOGENESIS AND RESTORATION OF LIMB MOTOR FUNCTION IN RATS WITH EXPERIMENTAL ISCHEMIC STROKE
}

\section{ABSTRACT}

Ischemic stroke is one of the leading causes of mortality and disability worldwide. Dispite the progress of medical knowledge and technologies, the rate of permanent neurological impairment in patients after stroke remains high and effective strategy of restorative treatment is still at the stage of experimental development. Restoration of nervous system functions after stroke implies the activation of endogenous reparative processes, such as angiogenesis, using sources of regenerative medicine, including cell and tissue transplantation. Development of optimal and safe methods of neurotransplantation for stroke is one of the priorities of experimental research in this field.

PURPOSE: to study the effect of post-stroke angiogenesis, stimulated by transplantation of cell suspension from embryonic nervous tissue (TCS-ENT) and bone marrow (TCS-BM), on restoration of motor functions in rats with experimental stroke.

MATERIALS AND METHODS. 160 adult (3-4 months old) outbred albino rats weighing between 280-320 g were divided into groups and subgroups depending on the experimental procedure: with isolated middle cerebral artery occlusion (MCAO), intracerebral allotransplantation of cell suspension from embryonic nervous tissue (MCAO + TCS-ENT), intracerebral autotransplantation of cell suspension from bone marrow $(M C A O+T C S-B M)$ or phosphate-buffered $0.9 \%$ saline infusion $(M C A O+P B S)$ on the $2^{\text {nd }}$ day after MCAO. MCAO was conducted using the modified method of intraluminal monofilament occlusion with blocking of collaterals. Volume of infarction zone was estimated using TTC staining on $7^{\text {th }}$ and $14^{\text {th }}$ day ( $n=5$ from each group on each day), number of vessels in periinfarct zone was calculated by immunohistochemical staining for CD34 on $7^{\text {th }}, 14^{\text {th }}$ and $28^{\text {th }}$ day ( $n=6$ from each group on each day) after MCAO. Motor deficit was assessed by ledged tapered beam-walking test on $1^{\text {st }}, 3^{\text {rd }}, 7^{\text {th }}, 14^{\text {th }}, 21^{\text {st }}$ and $28^{\text {th }}$ day after MCAO ( $n=18$ from each group on each day).

RESULTS. TCS-BM caused the increase in the number of vessels in the periinfarct zone in dynamics, most prominent on $28^{\text {th }}$ day, and decrease in the volume of infarction zone in comparison with other experimental groups, starting on $7^{\text {th }}$ day after MCAO. TCS-ENT and TCS-BM resulted in regression of motor deficit, starting from $3^{\text {rd }}$ and till $28^{\text {th }}$ day after MCAO. The degree of limb motor asymmetry in rats negatively correlated with the number of vessels in periinfarct zone.

CONCLUSION. Transplantation of cell suspension from embryonic nervous tissue and bone marrow promotes the regression of motor impairments in experimental animals due to angiogenic effect, which is more prominent in case of TCS-BM.

KEYWORDS: middle cerebral artery occlusion, embryonic nervous tissue, bone marrow, angiogenesis, motor deficit 
The relevance of rehabilitation of patients with ischemic stroke and its effects are evident in terms of significant social and economic impact of population mortality and disability caused by this pathology [25]. Despite the great diversity of currently existing treatments for patients with stroke, their therapeutic potential is limited in the time by the period of neurons' survival in the periinfarct zone - «penumbra» that are in a state of parabiosis [30]. Current therapeutic strategies for stroke are aimed at stimulating of structural and functional repair of these cells by restoring the perfusion of damaged brain areas and neutralization of pathophysiological alterational cascade caused by ischemia.

However, despite the rapid development of new medical technologies, a significant part of patients after stroke remains with persistent neurological deficits that complicates the social readaptation of these patients and is often resistant to modern methods of rehabilitation. Even in developed countries thrombolytic reperfusion by tissue plasminogen activator is applied in the acute stage of stroke no more than in 4-7 $\%$ of patients [30]. The expected therapeutic effect of neuroprotective drugs has not been conclusively proven in most clinical research, and the use of surgical revascularization techniques is a discussible issue. Activation of regenerative processes in the brain unlimited by the period of acute stroke is a fundamentally new direction of treatment the patients with this pathology [29]. As a key reparative mechanism in ischemic brain damage is angiogenesis. Stimulation of angiogenesis is a promising treatment for patients with stroke $[3,4]$. Therefore, growth factors, stem cells of different origins, means of genetic engineering and their combinations are used in clinical trials and experimental studies. Numerous experimental studies have demonstrated the positive impact of neurogenic stem cells (NSC) and bone marrow mesenchymal stem cells (BM-MSCs) on functional recovery of experimental animals after stroke modeling [11, 12, 15]. However, an effect of cells transplantation at stroke, including its effect on angiogenesis, has not been sufficiently studied. There are proves that the extracellular matrix, stroma and microenvironment may be a useful modulator of transplanted cells function including embryonic (ENT) and fetal neural tissue (FNT), and facilitate their integration in the brain of the recipient $[9,11]$. At the same time bone marrow, which is the source of MSCs, is successfully applied as a whole undissociated suspension to stimulate angiogenesis at ischemic lesions of the limbs and myocardium [3, 4]. Considering these stem cells sources to be the most available in Ukraine, there is a need to study the possibility of their use in cerebral revascularization at ischemic stroke in the preclinical stage.

Therefore, quantification of morphological and functional recovery of experimental animals becomes important after stroke modeling in the experiment. It will create preconditions for clinical testing of a capable method of post-ischemic angiogenesis stimulating in the future.

OBJECTIVE: To study the effect of post-stroke angiogenesis, stimulated by transplantation of embryonic neural tissue cell suspension and bone marrow, on the restoring of motor function in rats with experimental ischemic stroke.

\section{MATERIALS AND METHODS}

The study was conducted on 160 outbred albino male rats weighing between $280-320 \mathrm{~g}$ (3-4 months old) divided into three experimental groups and 12 subgroups. Group \# $1(n=72)$ - animals used for comparative evaluation of serial neurological deficit on $1^{\text {st }}, 3^{\text {rd }}, 7^{\text {th }}, 14^{\text {th }}$, $21^{\text {st }}$ and $28^{\text {th }}$ day of observation after stroke modeling: 1) subgroup \# $1(n=18)$ - animals with middle cerebral artery occlusion (MCA0) by the modified method («Control» - MCAO); 2) subgroup \# $2(n=18)-$ animals after MCAO with allotransplantation of embryonic neural tissue (MCAO + TCS-ENT) on $2^{\text {nd }}$ day; 3$)$ subgroup \# $3(n=18)$ - animals after $\mathrm{MCAO}$ with autotransplantation of bone marrow (MCAO + TCS-BM) on $2^{\text {nd }}$ day; 4) subgroup \# $4(n=18)$ - animals after the MCAO with intracerebral infusion of $0.9 \%$ phosphate buffer saline (MCAO + PBS) on $2^{\text {nd }}$ day.

Group \# $2(n=40)$ - animals that were used for morphometric assessment of cerebral infarction volume and were euthanazed on $7^{\text {th }}$ and $14^{\text {th }}$ days of experiment, respectively: 1 ) subgroup \# 5 (MCA0, $n=$ $10)$ - rats with MCAO that were euthanazed on $7^{\text {th }}(n=5)$ and $14^{\text {th }}$ day $(n=5)$ of the experiment after MCA0; 2$)$ subgroup \# 6 (MCAO + TCS-ENT, $n=10)$ - animals with TCS-ENT that were euthanazed on $7^{\text {th }}(n=5)$ and $14^{\text {th }}$ day $(n=5)$ of the experiment after MCAO; 3$)$ subgroup \# 7 (MCAO + TCS-BM, $n=10)$ - that were euthanazed on $7^{\text {th }}(n=5)$ and $14^{\text {th }}$ day $(n=5)$ of the experiment after MCA0; 4) subgroup \# 8 (MCAO + PBS, $n=10)$ - animals with PBS infusion on $2^{\text {nd }}$ day after modeling MCAO, which were euthanazed on $7^{\text {th }}(n=5)$ and $14^{\text {th }}$ day $(n=5)$ of the experiment after MCAO.

Group \# $3(n=72)$ - animals that were used for morphometric evaluation of the number of vessels in the periinfarct zone and were euthanazed on $7^{\text {th }}, 14^{\text {th }}$ and $28^{\text {th }}$ days after MCAO (6 animals from each group per day, including 24 animals from subgroups \# 1-4, which were euthanazed on $28^{\text {th }}$ day of observation): 1 ) subgroup \# 9 (MCAO, $\mathrm{n}=18$ ); 2) subgroup \# 10 (MCAO + TCS-ENT); 3) subgroup \#12 (MCAO + TCS$B M, n=18) ; 4$ ) subgroup \# 13 (MCAO + PBS, $n=18$ ). 11 pregnant female rats (15-16 day of gestation) were used to obtain ENT. All experiments were approved by the Ethics Committee of the 0 . 0 . Bogomolets National

Table 1. The distribution of animals by experimental groups and subgroups

\begin{tabular}{|c|c|c|c|c|c|c|c|c|c|c|c|c|c|c|}
\hline \multirow[b]{3}{*}{$\begin{array}{c}\text { DAY OF } \\
\text { EXAMINATION }\end{array}$} & \multicolumn{14}{|c|}{ EXPERIMENTAL GROUPS $(\mathrm{N}=160)$} \\
\hline & \multicolumn{7}{|c|}{$\begin{array}{c}\text { GROUP 1 } \\
(\mathrm{N}=72) \\
\text { EVALUATION OF MOVEMENT ASSYMETRY }\end{array}$} & \multicolumn{3}{|c|}{$\begin{array}{c}\text { GROUP } 2 \\
(\mathrm{~N}=40) \\
\text { MEASURING OF INFARCT } \\
\text { VOLUME }\end{array}$} & \multicolumn{4}{|c|}{$\begin{array}{c}\text { GROUP } 3 \\
(\mathbf{N}=72) \\
\text { IMMUNOHISTOCHEMISTRY }\end{array}$} \\
\hline & & 1 & 3 & 7 & 14 & 21 & 28 & & 7 & 14 & & 7 & 14 & 28 \\
\hline \multirow{4}{*}{$\begin{array}{c}\text { SUBGROUP } \\
\text { (ANIMALS } \\
\text { NUMBER) }\end{array}$} & $\begin{array}{c}\# 1 \text { (MCAO) } \\
n=18\end{array}$ & 18 & 18 & 18 & 18 & 18 & $18^{*}$ & $\begin{array}{c}\text { №5 (MCAO) } \\
n=10\end{array}$ & 5 & 5 & $\begin{array}{c}\text { №9 (MCAO) } \\
n=18\end{array}$ & 6 & 6 & 6 \\
\hline & $\begin{array}{c}\# 2 \text { (TCS-ENT) } \\
\mathrm{n}=18\end{array}$ & 18 & 18 & 18 & 18 & 18 & $18^{*}$ & $\underset{n=10}{\text { №6 (TCS-ENT) }}$ & 5 & 5 & $\begin{array}{c}\text { №10 (TCS-ENT) } \\
\mathrm{n}=18\end{array}$ & 6 & 6 & 6 \\
\hline & $\begin{array}{c}\# 3 \text { (TCS-BM) } \\
n=18\end{array}$ & 18 & 18 & 18 & 18 & 18 & $18^{*}$ & $\begin{array}{c}\text { №7 (TCS-BM) } \\
n=10\end{array}$ & 5 & 5 & $\begin{array}{c}\text { №11 (TCS-BM) } \\
\mathrm{n}=18\end{array}$ & 6 & 6 & 6 \\
\hline & $\begin{array}{c}\# 4 \text { (PBS) } \\
n=18\end{array}$ & 18 & 18 & 18 & 18 & 18 & $18^{*}$ & $\begin{array}{c}\text { №8 (PBS) } \\
n=10\end{array}$ & 5 & 5 & $\begin{array}{c}\text { №12 (PBS) } \\
\mathrm{n}=18\end{array}$ & 6 & 6 & 6 \\
\hline
\end{tabular}

Note: ${ }^{*}-6$ animals from each subgroup (\# 1-4) on the $28^{\text {th }}$ day were used for immunohistochemical study (total -24 animals). 
Medical University and conducted in compliance with the "Procedure for conducting experiments on animals by scientific institutions» (Ministry of Education, Youth and Sports of Ukraine \# 249, dated 01.03.2012).

Modeling of ischemic stroke. Since an analogue of ischemic stroke in rats is focal cerebral ischemia (FCI), for its experimental modeling we used a modification of permanent monofilament occlusion of the right middle cerebral artery, described in detail in previous studies $[5,6]$. Right common (CCA), external (ECA) and internal carotid (ICA) arteries were isolated from the midline incision of the neck under intraperitoneal anesthesia (sedazine $-10 \mathrm{mg} / \mathrm{kg}$ and calypsol $-75 \mathrm{mg} / \mathrm{kg}$ ). The vessels were cleaned off the connective tissue and nerves. Step by step ECA branches were coagulated, cut and pterygopalatine artery was ligated. Then a ligature around the ECA near the CCA bifurcation was fixed. Temporary microvascular clips were applied on CCA and ICA. ECA was incised at a distance of $1.2 \mathrm{~mm}$ from the CCA bifurcation. Using the ligatures the mobilized proximal end of ECA was pulled, and monofilament occluder 4/0 (Doccol corp., USA) was introduced. The ligature on the ECA stump was tightened, clips were removed and occluder was introduced intracranially until the feeling of light resistance, which testified the blocking of the middle cerebral artery. Then left CCA was ligated. In the simulation of «pseudoocclusion» monofilament was immediately removed after ICA blocking.

The suspension of bone marrow (BM) was obtained from the diaphysis of the left femoral bone of animals (group OSMA + TCS$\mathrm{BM})$ directly before transplantation by the method described in the literature with few modifications [2]. Under intraperitoneal anesthesia with a mixture of solutions calypsol $(75 \mathrm{mg} / \mathrm{kg})$ and xylazine $(10 \mathrm{mg} / \mathrm{kg})$ animals were fixed in the stereotactic device apparatus in the position on the abdomen, the skin in the region of the left thigh was straightly cut. After removal of soft tissue from the bone $3-4 \mathrm{~mm}^{3}$ of bone marrow was obtained and placed on the Petri dish with a warmed to $37{ }^{\circ} \mathrm{C}$ $0.9 \%$ saline. The bone marrow suspension was washed in $0.9 \%$ saline, multiple resuspended using pipette with $0.1 \mathrm{M}$ phosphate buffer solution $(\mathrm{pH}=7.4)$ for 10 minutes and placed in a vial with $5 \mathrm{ml}$ of this solution. In order to obtain a suspension of BM for transplantation the content of the vial was centrifuged at $2000 \mathrm{rpm}$ for $20 \mathrm{~min}$, and resuspended in $1 \mathrm{ml}$ of PBS. In such kind during craniotomy the suspension was held in an incubator at $37^{\circ} \mathrm{C}$ for $30-40$ minutes.

The cells suspension of embryonic neural tissue (ENT) was obtained from rat embryos on $15-16^{\text {th }}$ day of gestation by cesarean section of pregnant female rats. Embryos were removed from the horns of the uterus. Small pieces of bark and striatum of the brain were removed from them. Then they were incubated in saline PBS (Sigma, USA) for 15-20 minutes at room temperature, crushed with microscissors and dissociated via multiple absorption with glass Pasteur pipette with melted tips to prevent cells damaging. The resulting cell suspension was centrifuged at $1000 \mathrm{rpm}$, oversediment was poured and sediment cells were resuspended in Eagle's medium (Sigma, USA). The resulting cell suspension was kept in $\mathrm{CO}_{2}$ incubator (Nuve, Turkey) at $37^{\circ} \mathrm{C}$ and $5 \%$ $\mathrm{CO}_{2}$ until the transplantation.

Assessment of cells count and viability was carried out using haemocytometer after staining cells with a solution of $0.2 \%$ trypan blue. The total number of cells for transplantation in ENT suspension reached about $2 \cdot 10^{5}$ (content of viable cells $-68 \pm 3.1 \%$ ), in BM suspension $1 \cdot 10^{6}$ (content of viable cells $-87 \pm 2.9 \%$ ).

Methods of intracerebral transplantation. When choosing a period for conducting the intracerebral transplantation $\left(2^{\text {nd }}\right.$ day after MCAO modeling) we used the literature and data obtained in previous studies on the dynamics of recovery processes in the MCAO group $[5,6]$. Based on the data of numerous studies, we assumed that the specific effect of TCS-ENT and TCS-BM fully manifests at the early stage of neurovascular repair on 1-2 days after $\mathrm{FCl}[2,9,16]$.

Under intraperitoneal anesthesia with a mixture of calypsol $(75 \mathrm{mg} /$ $\mathrm{kg})$ and xylazine $(10 \mathrm{mg} / \mathrm{kg})$ animals were fixed in stereotactic apparatus in the position on the abdomen. The skull was exposed from the linear scalp incision, skeletotopical orientations were identified and the burr hole was made. Depending on the conditions of the experiment cell suspension $\left(1 \cdot 10^{6} \mathrm{BM}\right.$ cells in $20 \mu \mathrm{l}$ or $2 \cdot 10^{5}$ ENT cells in $\left.20 \mu \mathrm{l}\right)$ or the PBS $(20 \mu \mathrm{l})$ was injected intracerebrally at $5 \mu \mathrm{l} / \mathrm{min}$ with $26 \mathrm{G}$ Hamilton needle and automatic microinjector (Harvard Apparatus, USA) at the following coordinates: $0.3 \mathrm{~mm}$ posterior to bregma, $3 \mathrm{~mm}$ lateral (right) to the midline, $2.0 \mathrm{~mm}$ (cortex) and $4.0 \mathrm{~mm}$ (striatum) deep down of the dura mater, respectively. Thus, the solution was injected directly into the peri-infarct zone (PIZ), which corresponded to somatosensory cortex (10 $\mu \mathrm{l}$ at a depth of $2.0 \mathrm{~mm}$ ) and medial caudoputamen $(10 \mu \mathrm{l}$ at a depth of $4.0 \mathrm{~mm})$. After injection the cannula was left for 5 minutes in the cranial cavity for equable distribution of suspension and prevention of its outflow. Then the needle was removed and the burr hole was covered with medical Bone wax (Ethicon, USA).

Measurement of cerebral infarct volume was performed by staining of brain sections with 2,3,5-triphenyltetrazolium chloride - TTC (Sigma, USA). On the $7^{\text {th }}$ and the $14^{\text {th }}$ day animals were anesthetized with calypsol $(75 \mathrm{mg} / \mathrm{kg})$ and xylazine $(10 \mathrm{mg} / \mathrm{kg})$ intraperitoneally and tissue fixation was conducted in vivo using the transcardiac perfusion, after which animals were decapitated. The brain was washed in Petri dish with saline solution, and coronal $2 \mathrm{~mm}$-thick sections using a vibratome were performed. They were placed in $2 \%$ TTC solution for 15 minutes at 37 ${ }^{\circ} \mathrm{C}$. Then the sections were removed and laid out on graphpaper and scanned with a digital photo scanner CanoScan LiDE210 (Canon, Japan). Digital image processing and planimetric analysis of infarct foci size were performed using the ImageJ software (National Institutes of Health, USA, http://imagej.nih.gov) by the formula:

$$
\mathrm{S} 1=\mathrm{S}_{1 \mathrm{TC}}-\mathrm{S}_{1 \mathrm{Ni}}
$$

where $S_{1}$ - corrected infarct zone area, $S_{1 T C}$ - the total area of contralateral (intact) hemisphere, $S_{1 \mathrm{Ni}}$ - area of intact tissue in the affected cerebral hemisphere.

Corrected infarct volume value was received by the formula:

$V_{1}=\Sigma S_{1} \cdot n_{1}$,

where $S_{1}$ - corrected infarct zone area, $n_{1}$ - slice thickness, $\Sigma$ - sum of products of corrected infarct area and the slice thickness (depending on the number of slices).

The final relative value of damaged zone volume was presented as a percentage by the formula:

$$
\mathrm{V}=\mathrm{V}_{1} \mathrm{~N}_{\mathrm{Ni}}
$$

where $\mathrm{V}_{1}$ - corrected infarct zone volume, $\mathrm{V}_{\mathrm{Ni}}$ - intact cerebral hemisphere volume.

Immunohistochemical study of the brain tissue was performed using CD34 marker (DAKO, Denmark), which is expressed on endothelial cells, endothelial progenitor cells (EPCS), hematopoietic stem cells and progenitor cells [14]. For this purpose two- and three-step avidinbiotin method was used on $3.4 \mu \mathrm{m}$-thick sections of paraffin blocks. After dewaxing and dehydration to block endogenous peroxidase the sections were treated with $0.3 \%$ hydrogen peroxide solution for 20 min and washed in distilled water. Slices were incubated in a Target Retrievel Solution - TRS (DAKO, Denmark) with $\mathrm{pH}=6.0$ for 20 minutes using water bath to demask antigens. After washing three times in TRS for 5 min, a murine or rabbit primary antibody was applied. The incubation with the primary antibody was performed in a moist chamber for 30-60 minutes at room temperature. After incubation with primary antibodies the sections were washed in TRS three times for 5 minutes, then avidin-biotin complex conjugated with peroxidase was applied using $\mathrm{LSAB}^{+}$(DAKO, Denmark) for 30 minutes at room temperature or detection system EnVision+ ${ }^{+}$(DAKO, Denmark) for $30 \mathrm{~min}$ at room temperature. Detection of the peroxidase activity was performed using $\mathrm{DAB}^{+}$(DAKO, Denmark). Nuclei were stained with hematoxylin.

Counting the number of vessels in the peri-infarct zone was conducted on $2 \mathrm{~mm}$ brain slices $(0.3 \mathrm{~mm}$ posteriorly and $3.75 \mathrm{~mm}$ laterally from bregma) in 8 fields of view (see. Fig. 1), and then determined the average number of vessels in the field of view on $7^{\text {th }}, 14$ th and $28^{\text {th }}$ day after MCAO.

Evaluation of neurological disorders in animals was performed using the ledged tapered beam-walking test (LTBWT) on the $1^{\text {st }}, 3^{\text {rd }}, 7^{\text {th }}, 14^{\text {th }}, 21^{\text {st }}$ 
and $28^{\text {th }}$ days after modeling MCAO in subgroups \# 1-4 by the method described in the literature [25]. The presence of supports prevents compensatory motor strategies and helps identify the true deficit. While overcoming distance the number of animal paws foot-faults (slips) of the bar is taken into account. To facilitate the assessment of movement disorders the beam length is divided into three $45 \mathrm{~cm}$ segments, and the top board is painted in black. The end point of the way is a rats' cage containing food to encourage the animals to pass the distance on the beam. An intact rat easily learns to walk on a beam on the top board, rarely using supports (Fig. 2, A). An animal with MCAO uses a support for steps of paretic limbs on the appropriate side of the beam (Fig. 2, B). The affected limbs will rely on the support in the wide part of the beam more often than intact limbs and more often at the tapered of the beam.

The animals were trained for 5 days, 5 training periods per day. In the postoperative period five attempts in the session on each testing day were recorded. Every attempt was recorded using the camera and analyzed in a slow mode to calculate slips for each limb. Setting paws on the support is counted as full slips and incomplete (half) slips is when the limb touches the side of the beam. For each limb the number of slips is counted within five attempts. Then it is averaged, and the total number of steps for each segment of varying complexity is counted. After the unilateral damage, the number of ipsilateral and contralateral faults of the limbs on each segment is divided by the total number of steps on each segment. The percentage of asymmetry for each of the segments is calculated by subtracting the percentage of ipsilateral slips from the contralateral faults for one step. A larger percentage means more expresses lesion of contralateral limb. The end result of asymmetry for front (a) and hind (b) limbs was calculated by the formulas:

$\mathrm{a}=\left[\Sigma\left(\mathrm{x}_{1} / \mathrm{n}_{1}+\mathrm{x}_{2} / \mathrm{n}_{2}+\mathrm{x}_{3} / \mathrm{n}_{3}\right)-\Sigma\left(\mathrm{y}_{1} / \mathrm{n}_{1}+\mathrm{y}_{2} / \mathrm{n}_{2}+\mathrm{y}_{3} / \mathrm{n}_{3}\right)\right] / 5$,

$\mathrm{b}=\left[\Sigma\left(\mathrm{z}_{1} / \mathrm{m}_{1}+\mathrm{z}_{2} / \mathrm{m}_{2}+\mathrm{z}_{3} / \mathrm{m}_{3}\right)-\Sigma\left(\mathrm{s}_{1} / \mathrm{t}_{1}+\mathrm{s}_{2} / \mathrm{t}_{2}+\mathrm{s}_{3} / \mathrm{t}_{3}\right)\right] / 5$,

where $x_{1} / n_{1}, x_{2} / n_{2}, x_{3} / n_{3}$ - the number of slips divided by the number of steps for each way segment of the affected forelimb; $y_{1} / n_{1}, y_{2} / n_{2}, y_{3} / n_{3}-$ the number of slips divided by the number of steps for each way segment of the intact forelimb; $z_{1} / m_{1}, z_{2} / m_{2}, z_{3} / m_{3}$ - the number of slips divided by the number of steps for each segment of the affected hind limb; $\mathrm{s}_{1} / \mathrm{t}_{1}$, $\mathrm{s}_{2} / \mathrm{t}_{2}, \mathrm{~s}_{3} / \mathrm{t}_{3}$ - the number of slips divided by the number of steps for each segment of intact hind limb; 5 - the number of attempts.

Statistical data processing was performed using the software package SPSS 20.0 (IBM, USA) for the operating system OS X 10.9.4 (Apple, USA) using univariate analysis of variance with repeated measures function (oneway repeated measures analysis of variance - ANOVA) to compare groups \# 1-4 and two-way analysis of variance (2-Way ANOVA) for subgroups
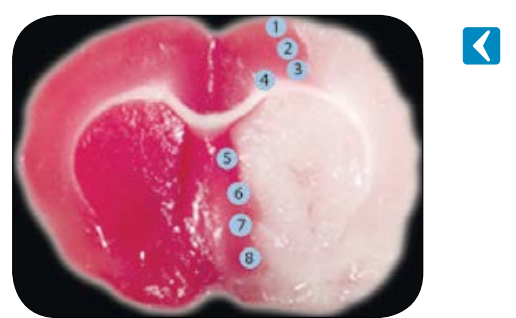

Fig. 1. Photo of the rat brain on the 7th day after MCAO and TTS staining. Infarct zone is white. Circles mark views, which were selected to quantify the angiogenesis in the periinfarct zone.
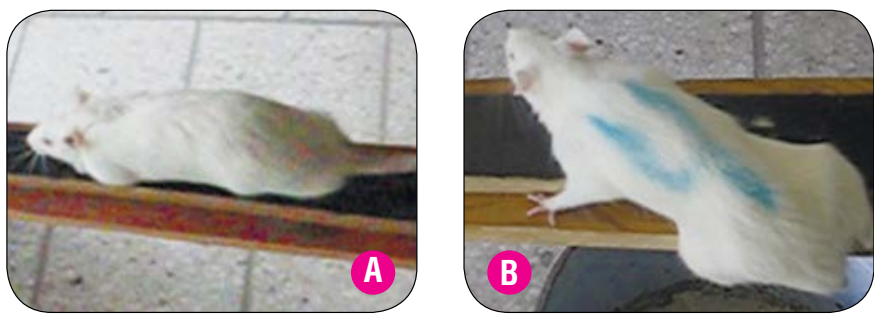

Fig. 2. Photo of ledged tapered beam-walking test. General view of the experimental room (A). Intact rat does not use supports when walking on the beam (A), while the rat with MCAO slips the affected limb (B)
\# 5-8 and \# 9-12. The analysis was carried out using option GLM (General Linear Models) and subsequent postprocessing (post-hoc testing) to identify differences between groups using Bonferroni and Scheffe tests. Correlation of morphometric data and movement disorders was performed using multiple regression analysis. The data were expressed as $\mathrm{M} \pm \mathrm{m}$, where $\mathrm{M}$ - arithmetic mean, and $\mathrm{m}$ - standard deviation. The difference is considered statistically significant when $p<0.05$.

\section{RESULTS AND DISCUSSION}

Immunohistochemical detection of CD34 marker in the vessels of the peri-infarct zone revealed an increase in the number of vessels in animals of all experimental groups from the $7^{\text {th }}$ to the $28^{\text {th }}$ day (Fig. 3, 4). In this case at all stages of observation there was significantly higher activity of angiogenesis in groups with tissue transplantation compared with groups MCAO and MCAO + PBS $(F=69.21, d f=3, p<0.001)$. When comparing the generalized average number of vessels in the groups of animals in the dynamics between the $7^{\text {th }}$ and $14^{\text {th }}(p=0.027$ by Scheffe and $p=0.022$ by Bonferroni), the $14^{\text {th }}$ and $28^{\text {th }}$ and the $7^{\text {th }}$ and $28^{\text {th }}$ days $(p<0.001)$ significant differences were also found. The greatest difference between the average number of vessels in the group MCAO + TCS-BM $(37.9 \pm 3.5)$ and MCAO + TCS-ENT $(30.8 \pm 2.6)$ is noted only on the $28^{\text {th }}$ day $(p=0.026$ by Scheffe and $p=0.015$ by Bonferroni). Instead, the difference between the average number of vessels in groups MCAO $\left(28^{\text {th }}\right.$ day $\left.-21.7 \pm 2.0\right)$ and MCAO + PBS (day $28^{\text {th }}-22.0 \pm 1.7$ ) was not significant.

Changes the size of cerebral infarction area on the $7^{\text {th }}$ and $14^{\text {th }}$ day after modeling focal cerebral ischemia $(\mathrm{FCl})$ and transplantation in different variants, including the placebo ( $0.1 \mathrm{M}$ phosphate buffer saline), is shown in Fig. 5. On the $7^{\text {th }}$ day after MCAO in animals of all experimental groups a clearly restricted area of ischemic necrosis of white color was observed, in contrast to the intact brain tissue that TTC dyed red (Fig. 6). TTC solution in $0.9 \%$ saline solution at $37{ }^{\circ} \mathrm{C}$ is colorless, but in living brain tissue under the influence of mitochondrial dehydrogenase is restored to red lipid-soluble formazan, while non-living tissue or infarction area remains unpainted [17]. Average volume of lesion areas, expressed as a percentage compared to the intact hemisphere, on the $7^{\text {th }}$ day after MCAO ( 5 day after transplantation in groups of transplantation) was significantly lower in the group MCAO + TCS-BM $(32.7 \pm 2.5 \%)$ than in the group with MCAO $(34.9 \pm 4.1 \%)$ and MCAO + PBS $(35.4 \pm 2.7 \%$; $\mathrm{df}=1, \mathrm{~F}=19,6, \mathrm{p}<0,001)$. It should be noted that a significant difference between the control group and the group «placebo transplantation» was found during the further observation period ( $p=0.968$ by Scheffe and $p=1.0$ by Bonferroni). A similar pattern was found and the comparison between a group MCAO + TCS-BM and MCAO + TCS-ENT $(p=0.429$ by Scheffe and $p=0.609$ for Bonferroni).

On the $14^{\text {th }}$ day in animals of all experimental groups we observed a decrease in the volume of the affected hemisphere in the control group of animals (MCAO $-34.9 \pm 4.1$ ), as well as in groups MCAO + TCS-ENT $(24.6 \pm 1.9)$ and MCAO + TSC-BM $(28.0 \pm 2.6)$. When comparing the average rate of generalized cerebral infarct volume in all experimental groups between the $7^{\text {th }}$ and $14^{\text {th }}$ day a significant difference between the times of observation $(p<0.001)$ was revealed.

According to LTBWT, a motor deficit manifested in rats on $1^{\text {st }}$ day after MCAO modeling and tended to a slight regression and stabilization to $28^{\text {th }}$ day of observation (Fig. 7). Highly significant differences in the average of motor dysfunction were observed between the two groups already on $3^{\text {rd }}$ day: MCAO + TCS-ENT $-66.6 \pm 1.4 \%$ when compared with the group MCAO $-73.4 \pm 1.6 \%, p<0.001$ and the group MCAO + PBS $(73.1 \pm 1.8, p=0.002)$ by Scheffe and Bonferroni; MCAO + TCS-BM $(59 \pm 2 \%)$ when compared with the group MCAO and the group MCAO + PBS, $p<0,001, F=26.97, d f=3$. This trend continued until the $28^{\text {th }}$ day of observation, when the average of motor asymmetry in MCAO group was $53.9 \pm 1.3 \%$ compared with groups TCS-ENT $(36.8 \pm 0.8 \%)$, and TCSBM $(21.9 \pm 1 \%, p<0.001)$. 
$\checkmark$

Fig. 3. Dynamics of the vessels number according to the immunohistochemical detection of CD34 in experimental animals of different groups.

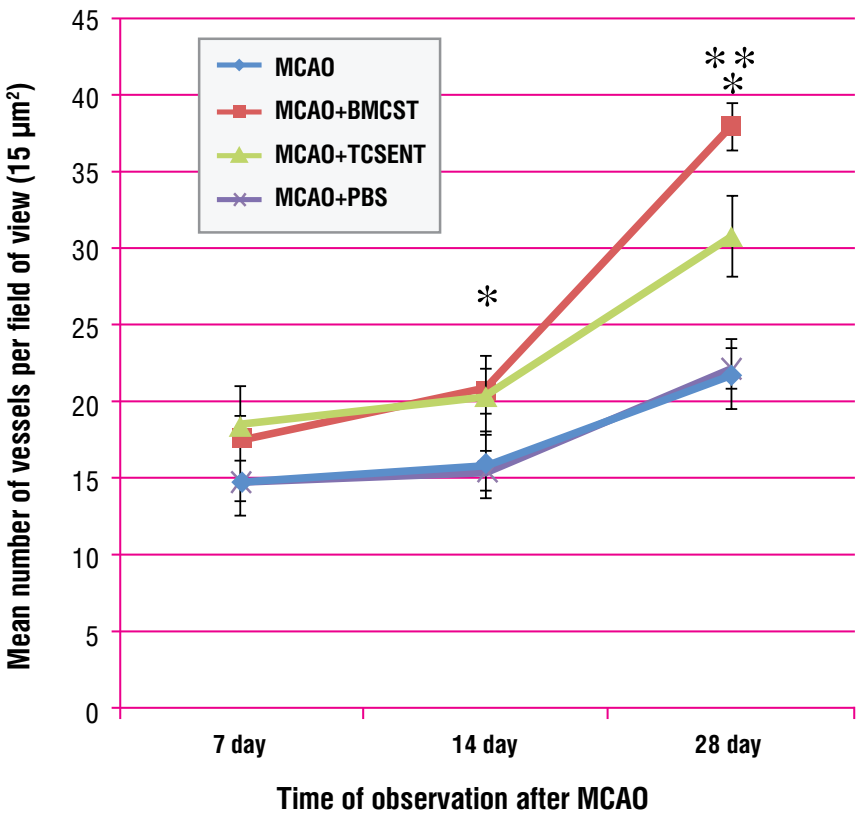

Note. * $-p<0.001$ compare between the control group and the placebo-transplant group and groups TCS-ENT and TCS-BM; ** $-p<0.05$ between groups TCS-ENT and MCAO.

It should be noted that differences in performance of motor asymmetry between groups MCAO + TCS-BM and MCAO + TCS-ENT during the observation period were statistically significant $(p=0.004$ by Scheffe and Bonferroni). The rate of motor function recovery in the opposite limbs at TCS-ENT reduced, starting from the $14^{\text {th }}$ day $(40.2 \pm$ $1.1 \%)$, whereas at TCS-BM kept positive dynamics from the $14^{\text {th }}(30.7 \pm$ $0.9 \%)$ to $21^{\text {st }}$ day $(22.7 \pm 1.1 \%)$.

No significant differences in index of motor asymmetry of rats in the control group and the group with PBS infusion was found $(p=0.953$ and 1.0 according to Scheffe and Bonferroni correction, respectively).

The data of multiple regression analysis indicate a strong negative correlation of motor asymmetry percentage of rat limbs and the number of vessels in the periinfarct zone (corrected R2 $=0.499$; standardized $\beta=-0.561, t=4.6, p<0.0001)$ and a weak positive correlation $(B=0.294$, $t=2.4, p=0.021$ ) of the volume indicator of cerebral infarction area (Fig. 8 and $\mathbf{9}$ ).

The analysis of infarction and angiogenesis zone volume demonstrates the positive impact of TCS-ENT and TCS-BM on the regeneration of brain tissue in the area of ischemic brain damage. This effect is already manifested on the $7^{\text {th }}$ day of observation after $\mathrm{FCl}$ and reaches its peak on the $28^{\text {th }}$ day $(\mathbf{F i g} . \mathbf{3}, \mathbf{5})$. On the $7^{\text {th }}$ day after MCAO there was an increase in the recovery rate of limbs motor function, and a maximum regression of motor disorders in groups with TCS-ENT and TCS-BM was also observed on the $28^{\text {th }}$ day. It should also be noted that the increase in the number of newly formed vessels in PIZ, especially pronounced in the group with TCS-BM, correlated with positive dynamics of motor limb asymmetry, confirming the effect of angiogenesis on the restoration of neurological function in experimental animals after FCl (Fig. 8). Morphometric analysis shows a positive effect of only TCS-BM on volume area of ischemic damage, unlike TCS-ENT

Thus, TCS-BM proved to be more effective method of FCI rehabilitation in the experiment due to its angiogenic and possibly neuroprotective effects on PIZ cells, accompanied by preservation of greater volume of brain tissue and regression of motor deficits in the experimental animals already at the early stages of observation $\left(7^{\text {th }}-14^{\text {th }}\right.$ day after MCAO).

Obtained data are partially confirmed by other researches that studied the effect of transplantation of NSCs or neurogenic progenitor cells (NPCs), and bone marrow MSCs on the restoration of neurological functions in experimental animals after $\mathrm{FCl}$ [19, 22, 28, and 30]. Researchers associate this effect with the differentiation of NSCs, which is the main source of embryonic nervous tissue, in mature functionally complete neurons that form synaptic contacts with recipient's neurons $[11,18,22]$. Some authors attribute the decrease in volume of cerebral infarction after $\mathrm{FCl}$ to this substitution effect of NSCs transplant $[7,8]$. Besides migration and neuronal differentiation, an important role in postischemic brain regeneration render to trophic influence of embryonic and fetal brain NSCs [1]. Some authors also indicate the possibility of cerebral angiogenesis stimulation in periinfarct zone using human embryonic NSCs [21]. However, the issue of full restitution of neural networks by NSCs and neural precursors remains discussible. Today some researchers primarily consider embryonic (fetal) brain cells as a means of neurotrophic effect $[1,22]$.

There is also no sufficient evidence of anatomic integration BM MSCs and their differentiation into fully functional neurons [12]. However, some authors note that reconstruction of neuronal circuits is not always a decisive precondition for functional recovery $[1,7]$.

Probably, different functional activity of ENT and BM cells is explained by different mechanisms of interaction of SCs, stroma and intercellular tissue matrix in recipient's brain microenvironment $[1,9]$.

The main components of bone marrow are MSCs, stroma and extracellular matrix [2, 4]. It is proved that transplanted BM MSCs can release soluble trophic factors and cytokines that trigger the process of endogenous repair of ischemic brain tissue and stimulate the production of neuroprotective agents and own reparative cells of the brain parenchyma. Production of trophic and growth factors is enhanced by stimulating of newly formed vessels from BM MSCs, which further activates the processes of brain plasticity and recovery of neurological function after
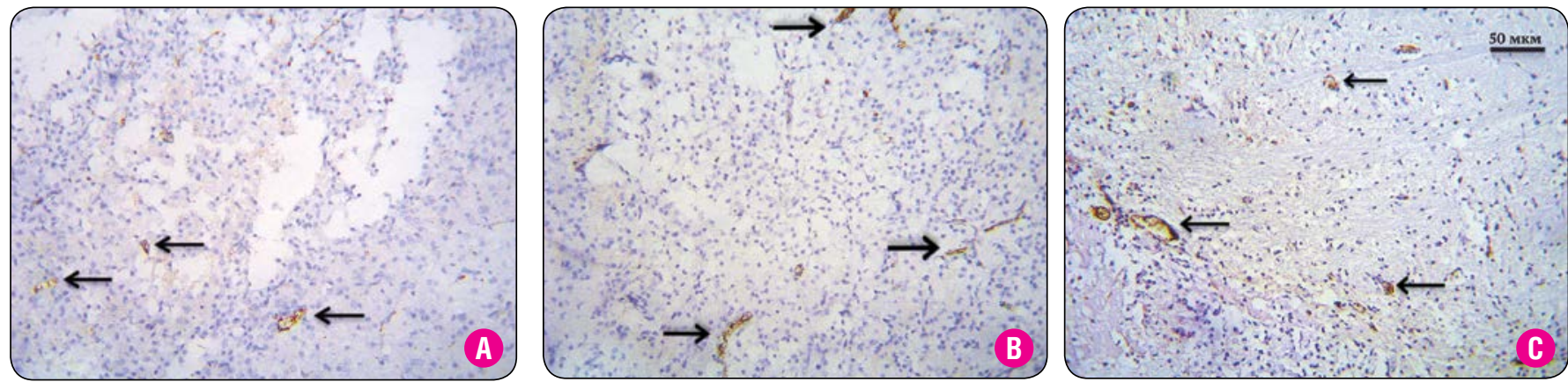

Fig. 4. Immunohistochemical staining of CD34 in endotheliocytes of newly formed blood vessels from peri-infarct zone on the $14^{\text {th }}$ day after MCAO A - control group, B - TCS-ENT, C - TCS-BM.

Note. Arrows indicate the vessels with CD34-positive cells. Staining: hematoxylin; anti-CD34 antibody (brown color). Scale - $50 \mu \mathrm{m}$ 
stroke [10]. Besides MSCs, direct role in neurovascular reparation after $\mathrm{FCl}$ takes nonhematopoietic BM stroma containing stromal progenitors with endotheliocyte phenotype $[19,31]$. In response to ischemia or cytokine stimulation there increases a mitotic activity of stromal progenitors and endothelial progenitor cells that launch the process of neovascularization in the inflammation. There is an assumption that MSCs are directly involved in angiogenesis, in which the latter act as EPCs [21, 31]. It is also proved that the molecules of the bone marrow extracellular matrix, including laminins, regulate the proliferation and differentiation of hematopoietic stem and progenitor cells $[9,19]$.

Our study found a weak correlation of changes in the volume of the affected cerebral hemisphere, determined by TTS staining of brain sections, with regression of motor deficit. A positive impact on infarct volume area was discovered only at TCS-BM. However, this effect is a subject of discussions [22, 26]. In particular Chen Y. et al. found no significant difference between the volume of lesion area in rats which underwent intracerebral transplantation of frozen bone marrow on the $7^{\text {th }}$ day after MCA0, compared with the control group on the $14^{\text {th }}$ day after MCAO [9]. But in the study of Li Y. et al. intravenous transplantation of bone marrow cells after a day after modeling $\mathrm{FCl}$ helped to significantly reduce an infarct area size on the $14^{\text {th }}$ day after MCAO, which was also accompanied by significant functional recovery in the animals of this group compared with the control group [19]. Similar results were also obtained in another study, where intracerebral transplantation of bone marrow stromal cells was carried out immediately after induction of focal cortical ischemia [26]. These differences can be explained by the use of different models of $\mathrm{FCl}$, in particular - transcranial MCA occlusion, which leads to a smaller damaged area, as well as temporary MCA occlusion followed by reperfusion [29].

Due to our use of the modified model of the permanent MCA occlusion, which leads to a stable, clearly defined zone of cerebral infarction, and early stages of transplantation ( $2^{\text {nd }}$ day after MCAO), we can assume that a positive BM impact on the volume of ischemic brain area is caused by nonspecific early neuroprotective and antiapoptic influence of cells transplant with proliferative potential that can prevent the death of neurons in the ischemic penumbra. This is confirmed by a decrease in the concentration of proinflammatory cytokines and neurospecific proteins, markers of neurodegeneration, and an increase in concentrations of inflammatory cytokines at the transplantation of BM MSCs [21].

Most morphological data, which allow to formulate reasonable assumptions regarding the mechanism of action of transplanted cells, were obtained at a fixed observation period and were not considered in dynamics. Instead, researchers recognized the need for long term monitoring of serial neurological disorders in animals with experimental stroke because the development of secondary degenerative and reparative processes after $\mathrm{FCl}$ in different anatomical and functional areas of the brain occurs at different times after an injury [13]. Considering the above, the mechanisms of action of different means and methods of cell and tissue transplantation at $\mathrm{FCl}$ should be considered in terms of their differential impact on spatial-temporal parameters of reparative processes in the affected area that requires a correlation of functional, morphological and morphometric data $[6,16]$. Our data indicate the existence of a relationship between activation of angiogenesis and improvement of neurological function in rats after MCAO and tissue transplantation.

Comparative comprehensive functional and morphological analysis of TCS-ENT and TCS-BM as a means of cell transplantation of various origins with potentially different mechanisms of action showed the benefits of TCS-BM, due to its predominant angiogenic effect, accompanied by regression of motor disorders in laboratory animals.

It has been proved that the development of collateral blood flow and functioning of the newly formed vessels in the brain perifocal zone after ischemic injury has a neuroprotective effect, promotes activation of neurogenesis in the subventricular zone of the lateral ventricles and the formation of new neural networks through trophic support within the so-called "neurovascular niche" [20]. In our study, using the CD34 immunohistochemical marker for endotheliocytes and EPCs detection in the newly formed blood vessels, angiogenic effect of tissue transplantation is observed on the $7^{\text {th }}$ day and reaches its maximum on $28^{\text {th }}$ day, which, according to some data, corresponds to the period of formation of a stable vascular network functioning [3,31]. Neovascularization was
Fig. 5. Diagram of cerebral infarction zone volume dynamics in rats after MCAO and different variants of intracerebral transplantation.

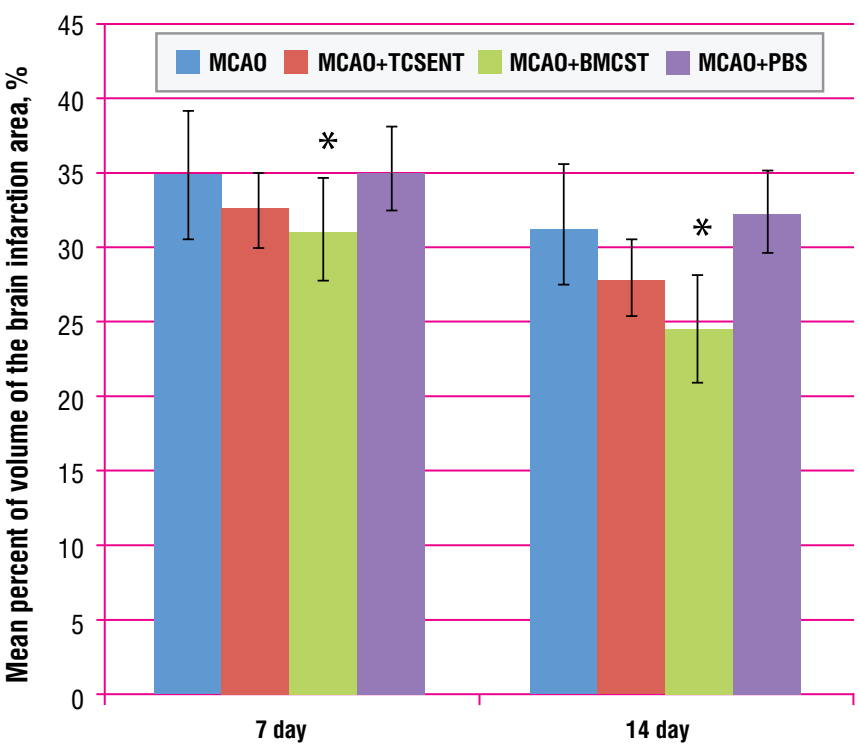

Time of observation after MCAO

Note. * - Statistically significant differences between groups MCAO + TCS-BM and MCAO ( $p=0.002$ by Scheffe) and MCAO + PBS $(p=0.007$ by Scheffe $)$
Fig. 6. Photo of rat brain sections on the $7^{\text {th }}$ and $14^{\text {th }}$ day after MCAO modeling, TTS staining.

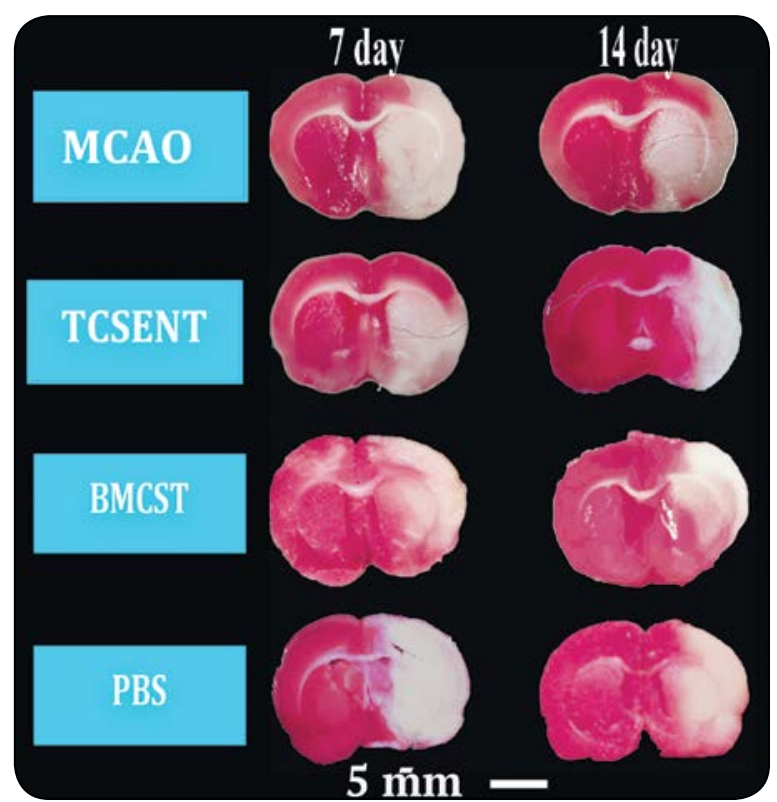

Note

TCS-ENT - MCAO + TCS-ENT group, TBM - MCAO + TCS-BM group,

$P B S-M C A O+P B S$ group. First row vertically $-7^{\text {th }}$ day,

second row $-14^{\text {th }}$ day. Scale $-5 \mathrm{~mm}$. 
also observed in the control group with MCAO and a group of «placebo» transplantation.

CD34 is one of the constitutive endothelial cell markers used in clinical trials of angiogenesis, particularly in oncology, along with other markers (vWF, SD31, SD45, CD 105, etc.) [14, 24]. This marker is also expressed by EPCs, which, according to various sources, are actively involved in post-stroke angiogenesis $[20,31]$. Thus, the definition of the CD34 expression allows us to identify not only endothelial cells, but EPCs in the wall of newly formed vessels that quantitatively demonstrates the activity of neoangiogenesis.

It should be noted that angiogenesis, stimulated by TBM, was more pronounced than at TCS-ENT ranging from the $14^{\text {th }}$ day to the end of the observation period. In our opinion, this is due to the powerful influence of different trophic cell subpopulations of BM, primarily stromal and hematopoietic stem cells and mononuclear cells secreting angiogenic growth factors and others $[9,21]$. EPCs from bone marrow can directly differentiate into endotheliocytes of newly formed blood vessels [31]. Restoration of microcirculation and perfusion in PIZ leads to the improvement of local metabolism in the ischemic area and thereby promotes survival of penumbra cells [20].

More pronounced functional effect of TCS-BM compared with TCSENT, is most likely caused by an primary activation of angiogenesis and sinaptogenesis, leading to demasking of latent and formation of interneuronal connections of the motor modality [15]. The accumulated data indicate that treatment of stroke using BM MSCs stimulates the formation of new neuronal networks in both ipsilateral and contralateral brain hemispheres [26]. There was shown BM MSCs ability to lower levels of inhibitory glycoproteins, which in its turn facilitate the sprouting of axons, and stimulate the production of neurotrophic factors by astrocytes, which are actively involved in the remodeling of the white matter of the brain [19]. Activated astrocytes can express angiogenic factors that contribute to the formation of a neurovascular «niche», which is the epicenter of the tissue reorganization, formation of new synaptic contacts and chemoattraction of endogenous neuroblasts from SVZ [20]. Recovery of motor function may also be associated with remodeling of the corticospinal tract at the level of the spinal cord at experimental stroke using BM MSCs [26]. Synaptogenesis is greatly enhanced in terms of activation of angiogenesis $[20,21]$. A strong correlation of the functional recovery with the activity of post ischemic cerebral angiogenesis may indicate a more pronounced BM effect on processes of neural plasticity.

\section{CONCLUSIONS}

Transplantation of bone marrow and embryonic nervous tissue in rats after MCAO contributes to the restoration of their limbs motor function. The rate and extent of regression of neurological deficit were higher at bone marrow transplantation, which is associated with the stimulation of angiogenesis in peri-infarct zone and reducing the volume of the affected hemisphere in experimental animals. The obtained data indicate the prospects of further study of the tissue transplants effects to justify terms, means and methods of transplantation for further implementation in clinical practice.
Fig. 7. Diagram of intracerebral transplantation impact on the motor asymmetry index according to the BWT.

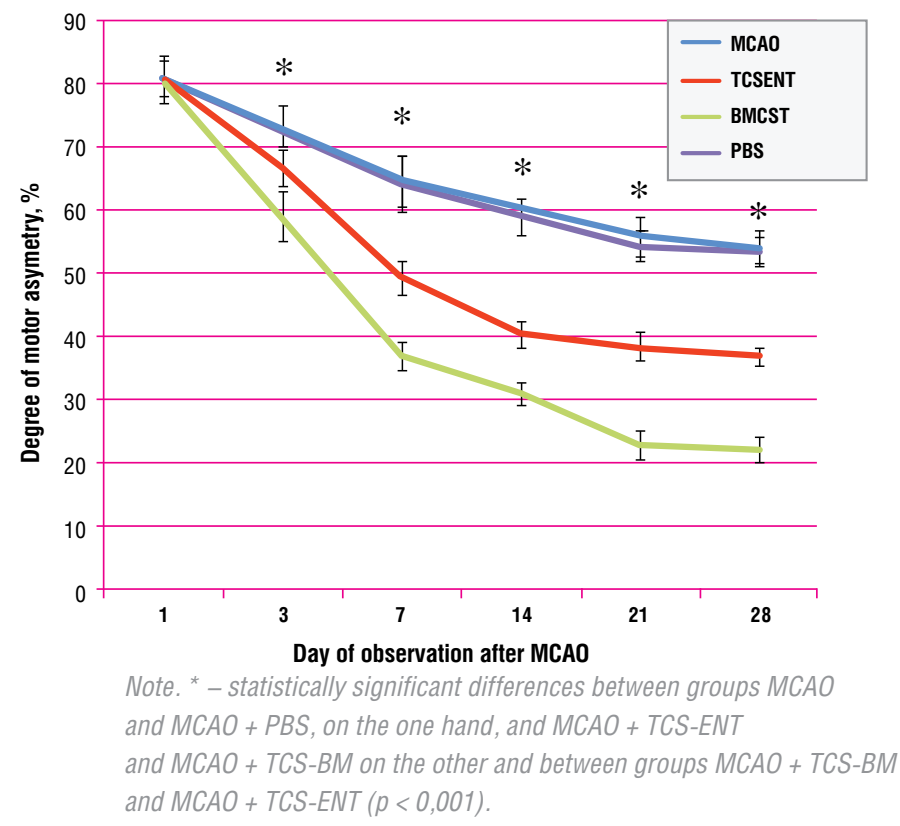

Fig. 8. Diagram of correlation of angiogenesis activity and motor asymmetry according to the multiple regression analysis.

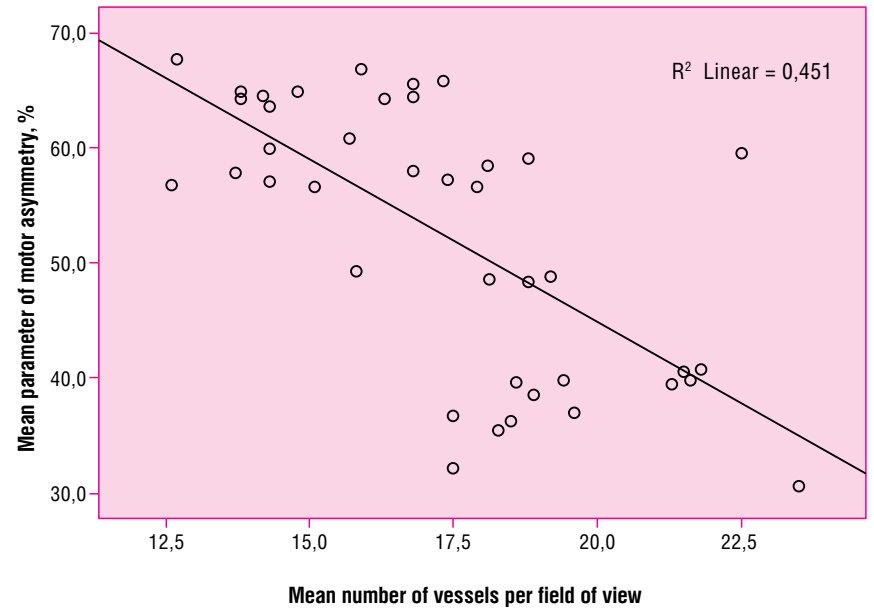

$\checkmark$ Fig. 9. Diagram of correlation of the cerebral infarction volume and motor asymmetry according to the multiple regression analysis.

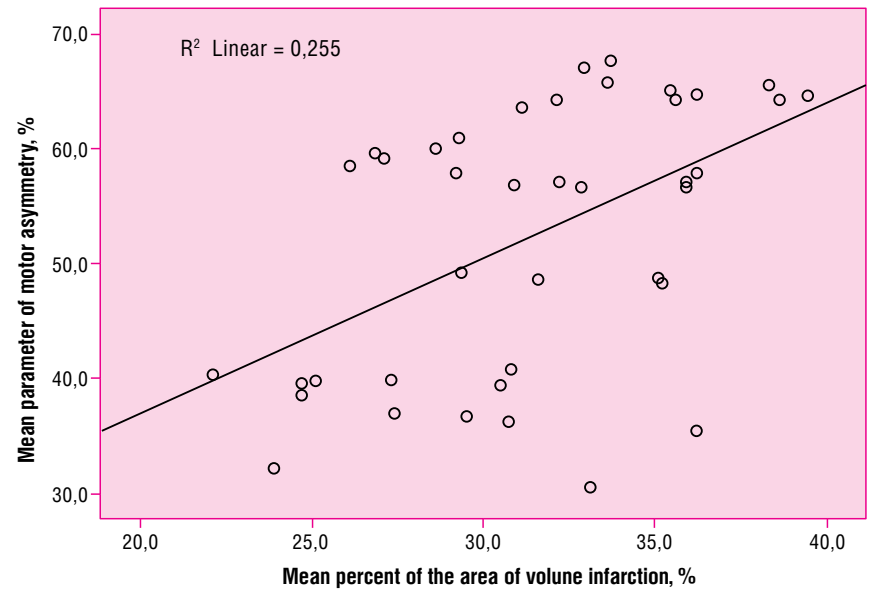




\section{REFERENCES}

1. Volkov Al, Lebedev SV, Viktorov IV, et al. Vlijanie transplantacii nejrogennyh stvolovyh kletok na vosstanovlenie funkcij CNS u krys s insul'tom v kore mozga [Effect of neural stem cells transplantation on the recovery of the central nervous system in rats with stroke in the cerebral cortex]. Zhurnal nevrologii i psihiatrii im. S. S. Korsakova - S. S. Korsakoff Journal of Neurology and Psychiatry. 2010; 12:64-72.

2. Gridina NYa, Medvedev VV, Serkiz OV, et al. Sposib pryzhyttjevogo zaboru klityn kistkovogo mozku shhuriv iz stegnovoi' kistky [A method of in vivo sampling of bone marrow cells from the femur of rats]. Patent Ukrai'na - Ukraine, Patent 46029, IPC A61B17/00, № 200904829. 2009 , bull. № 23.

3. Kirimov VI. Novye vozmozhnosti revaskuljarizacii konechnostej pri hronicheskoj ishemii: indukcija angiogeneza putem autotransplantacii aspirata kostnogo mozga u bol'nyh s obliterirujushhim aterosklerozom sosudov nizhnih konechnostej [New possibilities of the extremities revascularization in chronic ischemia: induction of angiogenesis by the bone marrow aspirate autotransplantation in the patients suffering obliterating atherosclerosis of the lower extremities vessels]. Klinichna hirurgija - Clinical Surgery. 2009; 5:27-29.

4. Potapov IV, Kirillov IA. Stimuljacija angiogeneza kak osnova reparativnogo morfogeneza pri ishemicheskom porazhenii miokarda [Stimulation of reparative angiogenesis as a basis of morphogenesis in ischemic myocardial injury]. Vestnik Ross. AMN - Bulletin of the Russ. AMS. 2007; 9:3-8.

5. Tsymbaliuk VI, Yarmoliuk YeS. Modyfikovana model' eksperymental'nogo ishemichnogo insul'tu v shhuriv z vykorystannjam monofilamentiv iz sylikonovym pokryttjam [A modified model of experimental ischemic stroke in rats using silicone coated monofilaments]. Ukrai'ns'kyj nevrologichnyj zhurnal - Ukrainian Neurology Journal. 2012; 4:97-105.

6. Yarmoliuk YeS. Dynamika funkcional'nyh porushen' pry riznyh variantah tkanynnoi' transplantacii' z metoju aktyvacii' angiogenezu na modeli fokal'noi' cerebral'noi' ishemii' v shhuriv [The dynamics of functional impairment in different variants of tissue transplantation to activate angiogenesis on the focal cerebral ischemia mode in rats]. Ukrai'ns'kyj naukovo-medychnyj molodizhnyj zhurnal - Ukrainian Scientific Medical Youth Journal. 2014; 82(3):123-127.

7. Andres R, Horie N, Slikker W, et al. Human neural stem cells enhance structural plasticity and axonal transport in the ischemic brain. Brain. $2011 ; \mathbf{1 3 4 : 1 7 7 7 - 1 7 8 9 .}$

8. Buhnemann C, Scholz A, Bernreuther $C$, et al. Neuronal differentiation of transplanted embryonic stem cell-derived precursors in stroke lesions of adult rats. Brain. 2006; 129(12):3238-3248

9. Chen J, Chopp M. Intracerebral transplantation of bone marrow with BDNF after MCAo in rat. Neuropharmacology. 2000; 39:711-716

10. Chen J-R, Cheng $G-Y$, Sheu $C-C$, et al. Transplanted bone marrow stromal cells migrate, differentiate and improve motor function in rats with experimentally induced cerebral stroke. J. Anat. 2008; 213:249-258.

11. Darsalia V, Kallur T, Kokaia Z. Survival, migration and neuronal differentiation of human fetal striatal and cortical neural stem cells grafted in stroke-damaged rat striatum. Eur. J. Neurosci. 2007; 26(3):605-614.

12. Deng $Y, Y e W B, H u Z Z$, et al. Intravenously administered BMSCs reduce neuronal apoptosis and promote neuronal proliferation through the release of VEGF after stroke in rats. Neurol. Res. 2010; 32(2):148-156.

13. Freret $T$, Schumann-Bard $P$, Boulouard $M$, et al. On the importance of long-term functional assessment after stroke to improve translation from bench to bedside. Experimental \& Translational Stroke Medicine. 2011; $\mathbf{3 ( 6 )}: 1-5$.

14. Garlanda C, Dejana E. Heterogeneity of endothelial cells. Specific markers. Arteriosclerosis, Thrombosis and Vascular Biology. 1997; 17:1193-1202.

15. Gutiérrez-Fernández $M$, Rodríges-Frutos $B$, Ramos-Cejudo J, et al. Effects of intravenous administration of allogenic bone marrow- and adipose tissue-derived mesenchymal stem cells on functional recovery and brain repair markers in experimental ischemic stroke. Stem Cell Research\&Therapy. 2013; 4(11):1-12

16. Hayashi T, Noshita N, Sugawara T, et al. Temporal profile of angiogenesis and expression of related genes in the brain after ischemia. J. Cereb. Blood Flow\&Metab. 2003; 23:166-180.

17. Isayama K, Pitts LH, Nishimura MC. Evaluation of 2,3,5-triphenyltetrazolium chloride staining to delineate rat brain infarcts. Stroke. $1991 ; 22: 1394-1398$.

18. Jin $\mathrm{K}, \mathrm{MaO} X-\mathrm{O}, \mathrm{Xe} \mathrm{L}$, et al. Transplantation of human neural precursor cells in matrigel scaffolding improves outcome from focal cerebral ischemia after delayed postischemic treatment in rats. J. Cereb. Blood Flow Metab. 2010; 30(3):534-544.

19. Li Y, Hua XM, Hua F, et al. Are bone marrow regenerative cells ideal seed cells for the treatment of cerebral ischemia? Neural. Regen. Res. 2013; 8(13):1201-1209.

20. Liman TG, Endres M. New vessels after stroke: postischemic neovascularization and regeneration. Cerebrovasc. Dis. 2012; 33:492-499.

21. Lu M, Zhu Z, Chopp M, et al. Intravenous administration of human bone marrow stromal cells induces angiogenesis in the ischemic boundary zone after stroke in rats. Circ. Res. 2003; 92:692-699.

22. Mattsson B, Sorensen J C, Zimmer J, et al. Neural grafting to experimental neocortical infarcts improves behavioral outcome and reduces thalamic atrophy in rats housed in enriched but not in standard environments. Stroke. 1997; 28:1225-1232.

23. Roger VL, Go AS, Lloyd-Jones DM, et al. Heart disease and stroke statistics - 2011 update: a report from the American Heart Association. Circulation. 2011; 123:18-29.

24. Sawfat MD, Habib F, Elayat $A$, et al. Morphometric analysis and immunohistochemical study of angiogenic marker expressions in invasive ductal carcinoma of human breast. Folia Morphol. (Warsz.). 2009; 68(3):144-155.

25. Schallert T, Woodlee MT. Orienting and placing. Behavior of the laboratory rat: a handbook with tests. Oxford: Oxford University Press. 2005; pp. 129-140.

26. Song M, Mohamad $0, \mathrm{Gu}$ X, et al. Restoration of intracortical and thalamocortical circuits after transplantation of bone marrow mesenchymal stem cells into the ischemic brain of mice. Cell Transplant. 2013; 22(4):15.

27. Tsai M-J, Tsai S-K, Hu B-R, et al. Recovery of neurological function of ischemic stroke by application of conditioned medium of bone marrow mesenchymal stem cells derived from normal and cerebral ischemia rats. Journal of Biomedical science. 2014; 21(5):1-12.

28. Vu Q, Xie K, Eckert M, et al. Meta-analysis of preclinical studies of mesenchymal stromal cells for ischemic stroke. Neurology. 2014; 82(14):1277-1286.

29. Woodruff TM, Thundyil J, Tang S-C, et al. Pathophysiology, treatment, and animal and cellular models of human ischemic stroke. Molecular Neurodegeneration. 2011; 6(11):1-19.

30. Zhang $P$, Li J, Liu $Y$, et al. Human embryonic neural stem cell transplantation increases subventricular zone cell proliferation and promotes peri-infarct angiogenesis after focal cerebral ischemia. Neuropathology. 2011; 31(4):384-391.

31. Zhang ZG, Zhang $L$, Zhang $Q$, et al. Bone marrow-derived endothelial progenitor cells participate in cerebral neovascularization after focal cerebral ischemia in the adult mouse. Circ. Res. 2002; 90:284-288.

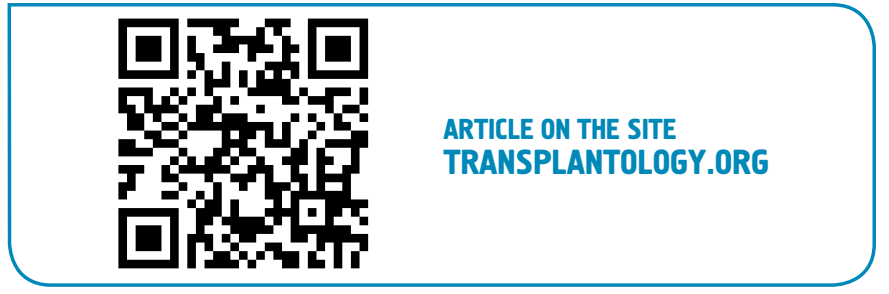

The authors indicate no potential conflicts of interest. 